\title{
Development of a Classification of Spanish Credit Institutions Based on the Concept of Stakeholder
}

\author{
Antoni Segui-Alcaraz \\ University of Valencia \\ Avda. dels Tarongers, s/n, 46022 Valencia, Spain \\ e-mail: antonisegui@coev.es \\ crossref http://dx.doi.org/10.5755/j01.ee.23.5.667
}

Corporate Social Responsibility (CSR) assumes that banks voluntarily incorporate social and environmental criteria in their economic activities and relationships with stakeholders. The reason why a credit institution decides to involve itself in social activities is a question which the literature on economics has tried to answer. We highlight the relationship created between the credit institution as a social organization and its various stakeholders, analyzing the importance assigned to each of them. Our goal is to find distinct profiles of credit institutions, depending on their degree of concern about CSR (Corporate Social Responsibility). The field work was conducted by means of a survey answered by 57 Spanish credit institutions. The results show the interest of such institutions in CSR in relation to the entire Spanish financial sector. Three clusters are distinguished according to how they think about CSR. In the first cluster there are institutions with responsibility focused on employees. It includes entities whose priority stakeholders are shareholders and employees. In the second cluster, we find institutions with responsibility focused on society. Among the stakeholders they act primarily towards customers, society and the environment. The third cluster is made up of institutions with responsibility focused on legislation (norms). In the third cluster, there is Friedman's vision, which considers the social responsibility of the bank as the maximization of Profit.

Keywords: corporate social responsibility, banks, taxonomy, employees, society, legislation.

\section{Introduction}

Corporate Social Responsibility (CSR, hereafter) is a subject which has been dealt with and studied for decades, although the importance it is acquiring in companies as well as in academia and even in politics has been very significant in recent years.

The reason why a credit institution decides to involve itself in social activities is a question which the literature on economics has tried to answer. Among the reasons there are the competitive advantage that CSR gives to enterprises (Waddock \& Graves, 1997; Porter \& Kramer, 2006; Bigne et al., 2005), the benefits associated with socially responsible behaviour in terms of reputation (Black et al., 2000), benefits which would outweigh the costs associated with the adoption of a socially responsible policy and which would therefore lead to an increase in productivity or business return (Moskowitz, 1972; Alexander \& Buchholz, 1982; Charlo \& Moya, 2010).

CSR assumes that banks voluntarily incorporate social and environmental criteria in their economic activities and relationships with stakeholders (European Commission, 2001). CSR turns the bilateral relationships between shareholders and employees into multilateral ones in which all stakeholders take part, including shareholders, employees, customers, suppliers, government, investors, the local community, and society in general (Cuervo, 2005).

This enhances the external and institutional image of the credit institution to the extent that it justifies their social role, reaching higher levels of credibility and recognition with the creation of values and identity. The purpose of this research is to find distinct profiles of credit institutions and effects in banks. First, based on a review of the literature, we present the theoretical elements corresponding to the stakeholders and the hypotheses arising from them. Subsequently, we discuss the method of research, analysis, results, and conclusions.

\section{Origins and evolution of the stakeholder concept}

Chronologically, the first definition of the word 'stakeholder' is found in the memorandum that the SRI (Stanford Research Institute) wrote in 1963 about the concept of business. This Institute defined the concept of stakeholder as the groups without whose support the organization would cease to exist (Freeman 1984).

This definition points to the central characteristic of the model credit institution, underlying the approach to stakeholders, which is the fact that a credit institution is not formed by just one or two stakeholders but by many other groups on which its long-term survival depends. And this is the distinctive feature which distinguishes the classical approaches of credit institutions, which focus on the shareholder or owner (stockholder or shareholder approach) from the multiple approaches of credit institutions, centred on the different stakeholders of credit institutions (stakeholder approach) (Brummer, 1991).

The fundamental differences between the two models can be summarized as follows: The shareholder-centred model is based on neoclassical economic theory, which basically states that the credit institution is and should be conducted according to the interests of the shareholders. 
The rationality in this approach is the maximization of the financial profit or of the value of the shares, so any action is justified if its aim is to increase the financial value of the company. The stakeholder model, meanwhile, is an attempt to integrate the basic idea that the credit institution has a responsibility from which arise specific obligations towards different groups, including shareholders, customers, employees, society, the environment and the Public Administration. It states that the credit institution has that responsibility because stakeholders have legitimate interests (demands or claims) in relation to issues such as product safety, non-discrimination in the workplace, environment protection, etc.

After this brief statement of the distinction between a focus centred on proprietors/shareholders and one that is centred on stakeholders, it should be noted that the above definition is incomplete in two senses. On the one hand, it only underscores the need of the organization to get support from other stakeholders to develop its activity, but it does not highlight the importance of the wealth that a credit institution brings to stakeholders. That is, it does not consider whether the credit institution has a positive or negative impact on the interests and expectations of stakeholders. On the other hand, it does not explain what matters to each of the related parties.

These deficiencies lead to one of definitions of stakeholders in use today, and which has become a classic in literature, the one stated by Freeman (1984):

"Any group or individual who may affect or be affected by the achievement of the objectives of the company".

This definition incorporates the sense of the "support" of the groups to the credit institution that the SRI mentioned, but in a much more concrete way, because it no longer emphasizes success, which can be a very abstract concept, but goals, decisions or policies of the credit institution. Thus, this definition goes beyond the "support" part of stakeholder because, first, the relationship is not a one-way, but a two-way relationship that takes into account both the outcome of strategies and the policies employed to achieve them. Secondly, this definition of stakeholders contains not only the people that facilitate or hinder business, but also the credit institution, which is seen as a group that can help or hinder the achievement of the stakeholders' interests, rights or property. In addition, A. B. Carroll (1999) gives the following definition:

"A stakeholder is an individual or group that claims to have one or more types of interests in a company, when the interested parties can be affected by the actions, decisions, policies or practices of the organization."

The underlying subject of the concept of stakeholder should be used to direct the credit institution towards the financial goals it requires for its survival in the market, or, conversely, the inclusion of the point of view of stakeholders in the designs of the credit institution should go beyond pure strategy, and its aim should be to treat them in accordance with a long-term outlook in the business plan. This latter position leads us to look at how to define CSR. Not every group will support the credit institution, but only those groups that have legitimate interests (demands).

One of the most interesting points of view has been offered by Goodpaster (1979), who tries to offer an innovative proposal which includes the stakeholder approach in both its strategic and its regulatory uses. His proposal is to distinguish two aspects in the use of such concept: a "strategic" and a "multi-fiduciary" one, so as to be able to propose a mixed approach which he entitles "Stakeholder synthesis" (Carroll, 1989).

From his point of view, the vision or "strategic approach" of the stakeholder model involves the credit institution's perceiving stakeholders as important elements to be considered and managed with the ultimate aim of obtaining financial benefits for its shareholders. According to this view, attention is given to stakeholders because they are capable of creating resistance to, or relevant support for, the policies, actions or strategies of the credit institution. The author concludes that for this reason stakeholders are instruments that can facilitate or impede the objectives of the entity.

The weaknesses of this opinion about stakeholders are of a different nature, the first being that the stakeholder model as such is merely a plural variant, but a variation after all, of the approach centred on the interests of shareholders. This means that this position cannot be considered as a different approach, but as a variation of another one. The second weakness is contemplated from the point of view of a corporate integrated application, because, according to this interpretation of the stakeholder model, the responsibility of the credit institution towards the interests of stakeholders as such is denied, and it regards them only as a means to achieve the maximum financial profit for the shareholders.

The second view of the stakeholder approach is named by Goodpaster (1988) the "multi-fiduciary approach". According to this, the credit institution considers stakeholders as elements towards whom the credit institution has a responsibility similar to that which it has towards shareholders. That is, the credit institution has an obligation to consumers and workers to the same extent as to shareholders and proprietors. Therefore, the neutrality required in the management of the credit institution under a multi-fiduciary approach is undermined from the outset, because there is no possibility of a balance of interests on the part of such management, since the legal aspect takes precedence. The study of these two approaches leads Goodpaster to recommend a synthesis of the two visions. This view states that the credit institution has social responsibility towards stakeholders because they have an intrinsic value, but it cannot be demanded that the basic fiduciary responsibility of credit institutions toward shareholders lose prominence. In this regard, it states that it is possible to keep the pre-eminence of corporate responsibility in respect of its shareholders, but always within a broader social and socially responsible framework. In his opinion, this social responsibility is a duty or obligation of the credit institution in the sense of doing no harm, blackmail, theft, etc. That is, the credit institution must continue to maintain a shareholder-centred focus, but with the broader perspective provided by the social framework and from which a credit institution cannot escape, even at the risk of jeopardizing the financial benefits of shareholders. Thus, shareholders cannot expect their managers to adopt behaviour which is inconsistent with the reasonable expectations of the community. 
In these circumstances it seems necessary to seek and provide a stakeholder model which would enable the administration and management of the credit institution to be understood and implemented, both strategically and when oriented towards the consensus or understanding resulting from the rational dialogue about the true interests of the different stakeholders (Lozano, 1997). In this regard, it is noticed that the responsibility of the administration and management of a credit institution involves not only the responsibility for the operations or strategies undertaken, but also a responsibility toward society.

Dunham and Liedtka (2006) develop the need to clarify the significance of interest groups. Thus Freeman (2004) defines stakeholders as "those groups who can affect or be affected by the achievement of the purposes of the organization", but also presents a distinction between various types of interest groups: the primary or definitional and the instrumental stakeholders. The primaries are vital to the continued growth and survival of any company, while stakeholders are instrumental in the broad environment of the company, and are those who can influence the primaries (activists, competitors, environmentalists, media).

Overall, it appears that, over time, Freeman has been slightly modifying the concept of the interest group, but has always maintained a remarkable loyalty to its original definition.

\section{Classification of stakeholders}

Since 1963, when the S.R.I. included shareholders, owners, employees, customers, suppliers, loan entities and society as stakeholders in credit institutions (Freeman, 1984; Kitson \& Campbell, 1996), many pragmatic criteria may be found for the classification of stakeholders (Carroll, 1991; Freeman, 1984; Wheeler \& Sillanpaa, 1997).

The first classification attempt was made by W. M. Evan and R. E. Freeman (1979), on the basis of stakeholders' need for the existence or survival of the credit institution. Thus, these authors distinguish two concepts of stakeholder, a limited and a broad one.

On the one hand, the limited definition includes those groups that are vital to the survival and success of the credit institution, thus following the definition of the term held by the SRI in 1963. Within this group are commonly included: employees, customers, suppliers, public administration and owners/shareholders, although, as has already been stated, this will depend on each credit institution. On the other hand, the broad definition includes some groups or individuals that may affect or be affected by decisions, policies or strategies of the company. This group would include the stakeholders, as well as employees, customers, owners, etc. In short, all those groups are that still remain vital to the survival of the credit institution, and which affect or may be affected by its activity.

The difficulties in the interpretation of the classification criteria used by Evan and Freeman (1979) resulted in the formulation of other criteria that allow one to classify business stakeholders in a more comprehensive way. In this sense, one of the more successful classifications has been the distinction between internal and external groups in relation to the credit institution. In this case, the criterion for classifying the stakeholders of the organization is 'the physical walls' of the organization and the effect this has on its relationship with the environment. Normally, the following have been included as external stakeholders: the public administration, environmentalists, particular groups of interest, the local community, society at large, the Mean and so forth. These stakeholders are defined as groups or individuals within the environment of the credit institution which affect its activity. As internal groups, the following are often considered: shareholders/owners, employees, suppliers and customers. These groups are generically defined as groups or individuals that are not strictly part of the environment of the entity.

It is important to point out the evolution that $\mathrm{RE}$ Freeman's thoughts have undergone, regarding the inclusion of certain groups as stakeholders of the credit institution, primarily in relation to the external ones. Concerning the groups to be considered among external stakeholders, in his work of 1984, competitors are present as external stakeholders.

According to the contractual theory of the credit institution, owners agree, with internal and external stakeholders, conditions under which they will contribute to production in exchange for a previously specified payment. In this way, the problem of sharing the value of the product would be solved: each participant, in accordance with the contract, receives the agreed share (employees, their salary; creditors, their interest...), noncontractual participants also receive a predetermined share (e.g. the State collects taxes) and owners receive what remains (profit). The same applies to risk: contractual participants receive their pay without risk, and any residual risk rests on the owners. And if they accept profit and residual risk, the decision-making is theirs (which they would delegate to managers through an agent agreement) and the corresponding control of the other actors through market or internal control mechanisms (Easterbrook \& Fischel, 1991).

We consider that the actions of a credit institution and its response to any interested party depend largely on the needs of that party (Henriques \& Sadorsky, 1999).

On the other hand, response gets complicated when there are incomplete contracts (for example, those which are incomplete because of information asymmetries, which cause opportunistic behaviour that neither the law nor the contract may avoid), external effects (contracts involving stakeholders who do not enter into the contractual relationships, such as future generations), or when specific capital investments take place, because they create risks that cannot always be transferred to the owner of capital, or when quasi-rents (similar to larger opportunities for profit attributable to that specific capital), have to be distributed. The criterion for the sharing of these risks and quasi-rents will have effects on the incentives of the parties involved and therefore on the fate of the credit institution.

\section{Corporate Social Responsibility and Banks}

Credit institutions have the responsibility to provide individuals with access to financial services (savings or current accounts, loans, transfer forms, advice, etc.) in the 
best possible conditions in terms of return, cost and risk. This access is usually available to those individuals with the potential to be profitable as customers.

It is clear that business responds to multiple stakeholders for myriad reasons in different ways (Berrone et al., 2007, Brickson, 2007; Clarkson, 1995; Jones et al., 2007). The proposed framework delineates this variety of approaches to stakeholders parsimoniously into a finite number of four configurations that explain their broad CSR approaches.

Approaches to stakeholders are a way of accessing aspects of CSR (Jamali, 2008) and expressing organizational identity (Berrone et al., 2007; Brickson, 2005, 2007). Phillips (2003) regards the stakeholder domain as notably applicable to organizational analysis. He argues that one of the features of the social responsibility of organizations is that they have "substantive aims". In the configurational approach, the firm is deemed to have visions, strategies, goals, and responsibilities. A perspective of organizations as responsible entities perceives them as possessing a social responsibility of their own, with intent towards stakeholders and a capacity to act in favour of or against their interests (Moir, 2001; Pruzan, 2001). The corporation has a "personality" that reflects modes of thinking, behaviour, values, and corporate identity (Kay, 1997; Van de Ven, 2008).

Bank is a social organization involving other areas to which it is connected, and in order to develop a relationship, the other party should be given sufficient reasons to do so. What must also be studied or considered is the "capacity" of the company and its size and potential for re-organization; furthermore, the concept of compensatory justice, by which the community contributes to the benefit the corporation gets from allowing it the use of certain resources (urban areas, human resources, infrastructure, investment in equipment, sporting events, educational projects, environmental projects, ...) may be applicable.

CSR presents a new, broader, and more inclusive concept of credit institutions, as it includes not only economic but also social and environmental aspects. Thus, the work of Carroll (1991) states that CSR requires credit institutions to try to meet the economic, legal, and discretionary expectations of all stakeholders, not just those of shareholders. Therefore, CSR is closely linked to the three principles that guide sustainable development: economic prosperity, environmental integrity, and social equity. In this respect, Certo and Peter (1996) distinguish three areas within the CSR: socio-economic, quality of life, and social investment.

Internationally, the major financial groups increasingly let social policies and environmental (Lee \& Miller, 1990; Baker \& Collins, 2010) responsibility to play a more important role, something which is being increasingly valued by employees, customers, investors, and society as a whole (Lozano et al., 2005). Behind these policies there is the general concept that socially responsible actions of banks are good (Pearson, 2005), not only in themselves, but also as a strategic investment that benefits the institutions. Therefore, an adequate social and environmental policy (Kessler, 2008; Ayyagari et al., 2008) has positive effects on the societies in which the entities exist, as well as on their image and economic development as a consequence of the policy's effect on three key groups: employees, customers, and owners/shareholders, in addition to society in general. In addition, via the provision of funding, credit institutions contribute to the implementation of all projects and activities (Scholtens, 2006).

The credit institution is also a social organization in another sense: as a part of a larger society. So what was expressed above on the subject of domestic stakeholders is also valid, in some way, for this inclusion of the credit institution in society, that is to say, for its relations with external stakeholders. Thus the following hypothesis arises:

We expect to find distinct profiles and effects of credit institutions, depending on their degree of concern for CSR and the importance given to different stakeholders.

After reviewing the literature supporting our research, we turn to commenting on fieldwork.

\section{Methods used to conduct fieldwork}

As a resource for obtaining information, we have chosen a survey of credit institutions. Thus, the fieldwork has been based on collecting the points of view of different credit institutions through this survey.

Table 1

Technical details of the research

\begin{tabular}{|l|l|}
\hline & 107 credit institutions with \\
& customer funds $>700$ mill. EUR \\
& -39 banks; \\
& -44 savings banks; \\
& -24 credit unions. \\
\hline Sample design & Simple random sampling \\
\hline & Responsible for CSR survey of the \\
Type of survey. & state, through a structured and \\
& codified online questionnaire. \\
\hline Desired degree of confidence & $95 \%$ \\
\hline Questionnaires sent: & 84 to obtain a sampling error of 5\% \\
\hline Questionnaires: & $57(68 \%$ response rate) \\
\hline \multirow{2}{*}{ Sampling error: } & $8,82 \%$ for a confidence interval of \\
& 1,96 (95\%) with p=q=0,5. \\
\hline Fieldwork: & The researcher \\
\hline Date: & July $2-$ September $27,2007$. \\
\hline Statistical analysis & Clusters \\
\hline Software used & Differences among groups (Tukey) \\
\hline \multicolumn{1}{|c|}{ Source: author } & SPSS 15.0 \\
\hline
\end{tabular}

\section{The survey}

To select the range of analysis, focusing on Spain's largest credit institutions, we used the criterion of liability of institutions with more than 700 million euro of "customer funds" on December 31, 2006.

We used data from the balance sheets of the Confederation of Savings Banks (CECA), the National Union of Credit Cooperatives (UNACC), and the Spanish Banking Association (AEB), while considering the structure and evolution of the institutions under supervision of the Bank of Spain in 2006.

We developed an analytical survey to attempt to prove hypotheses about the relationships between variables in order to understand and explain a particular social phenomenon.

This section presents not only the technical aspects whose theoretical enquiries guided the questionnaire and 
its coding, but also those carried out with the collaboration of many specialists: the AEB, the CECA, banks, savings banks, major banking trade unions (CCOO, UGT), and scholars, as well as pilot tests which we made on the questionnaire before beginning the survey itself.

\section{Pilot testing}

In order to test the applicability of the survey and the relevance of the questions (Kolk, 2005), Delphi methodology was applied in:

1. Representatives of two of the most important banking trade unions (CCOO, UGT) (committees) at the national level;

2. Representatives of corporations and the most important credit institution associations, the AEB and the CECA;

3. Executives responsible for the subject at Bancaja, CAM, and Banesto.

Following each of these tests, appropriate changes were made in order to achieve the final version of the questionnaire used. The survey questions have been validated by Specialist professors of the subject in a Scientific Congress called EBEN.

Note that the tests were sent by e-mail, as this channel seemed satisfactory in order to achieve our goals. The survey was answered via an online questionnaire.

\section{Statistical methods}

The technique of cluster or cluster classification aims to divide all credit institutions, into groups in such a way that those belonging to the same group are very similar to each other in relation to one factor, but very different from entities belonging to other groups (Hair, 1995). We will use the K-means algorithm, in order to find the optimal number of clusters.

Then we proceed to the validation of the model, to ensure that the solution is representative of the population, and will be applicable to other credit institutions that are not in the sample and will be stable over time. So we perform another non-hierarchical analysis, without applying the centroid of departure, and we let it set randomly using the SPSS application (Johnson, 1998).

As a second step we apply the analysis of variance (ANOVA) because it is a statistical method to determine whether a particular variable of social responsibility takes the same or different average values in the groups formed by another variable (Uriel, 1995).

So it is important to know what kind of scales should be used to measure each of the variables, and the factor, or independent variable, must be a nominal variable. In our case when working with SPSS, we'll see if the ANOVA shows that one average is unlike the others, then we shall perform several post hoc, multiple comparison tests to detect which average is different from which (Hatcher \& Stepanski, 1994).

We also perform Tukeys post-hoc analysis, in order to contrast the significant differences in pairs of elements.

The questionnaire was then submitted to the heads of CSR of different credit institutions.

\section{Results of the survey of credit institutions}

In this section we describe and discuss the results obtained in the test of the hypothesis set out in section two, point one of this article.

In order to implement a method of assessment of the attitude of credit institutions towards CSR, we will set up a taxonomy of Spanish credit institutions.

Characterization of clusters of Spanish credit institutions

Table 2

\begin{tabular}{|c|c|c|c|c|}
\hline \multicolumn{5}{|l|}{ Type of entity (\% of total) } \\
\hline Savings banks & 11.8 & 70.6 & 17.6 & \multirow{3}{*}{$\begin{array}{l}\text { Independence contrast: } \\
\text { Chi } 2=19.82(p=0.000)\end{array}$} \\
\hline Credit Unions & 55.6 & 22.2 & 22.2 & \\
\hline Banks & 95.0 & 5.0 & $\mathbf{0 . 0}$ & \\
\hline Variable & C I & $\mathbf{C 2}$ & $\mathbf{C 3}$ & $\begin{array}{c}\begin{array}{c}\text { Differences among groups } \\
\text { (Tukey) }\end{array} \\
\end{array}$ \\
\hline \multicolumn{5}{|l|}{ Assessment of stakeholders } \\
\hline Shareholders & High & Low & High & $1-2,2-3$ \\
\hline Customers & Mean & High & Low & $1-2,1-3,2-3$ \\
\hline Suppliers & Low & Low & High & $1-3,2-3$ \\
\hline AAPP & Low & Low & High & $1-3,2-3$ \\
\hline Employees & High & - & Low & $1-3$ \\
\hline Society & Mean & High & Low & $1-2,1-3,2-3$ \\
\hline Environment & Low & High & - & $1-2$ \\
\hline \multicolumn{5}{|l|}{ Employee-focused actions } \\
\hline Development of good alimentary practices & Mean & High & Low & $1-2,1-3$ \\
\hline For children & High & High & Low & $1-3,2-3$ \\
\hline Adoption & High & Low & Low & $1-2,1-3$ \\
\hline \multicolumn{5}{|l|}{ Suppliers } \\
\hline Open tender & Low & High & Low & $1-2$ \\
\hline Supplier procedure not available & High & Low & Low & $1-2$ \\
\hline Purchase procedure for investment propriety suppliers & Low & High & Low & $1-2$ \\
\hline U.N.O.World Pact & High & Low & Low & $1-2,1-3$ \\
\hline \multicolumn{5}{|l|}{ Social actions } \\
\hline Investments for community & Low & - & High & $1-2$ \\
\hline Educational projects & High & Low & Low & $1-2,1-3$ \\
\hline
\end{tabular}




\begin{tabular}{|c|c|c|c|c|}
\hline \multicolumn{5}{|l|}{ Type of entity (\% of total) } \\
\hline Cultural projects & Low & Low & High & $1-3,2-3$ \\
\hline Other & Low & High & Low & $1-2,2-3$ \\
\hline \multicolumn{5}{|l|}{ Environmental actions } \\
\hline Environmental policy available & Low & High & Low & $1-2$ \\
\hline Carry out an environmental corrective approach & Low & High & Low & $1-2,2-3$ \\
\hline \multicolumn{5}{|l|}{ Type of contribution to social action } \\
\hline In cash & High & Low & Low & $1-2$ \\
\hline In Management expenses & Low & High & Low & $1-2$ \\
\hline Other & Low & Low & High & $1-3,2-3$ \\
\hline \multicolumn{5}{|l|}{ Use of standards } \\
\hline (AA) 1000 & High & Low & Low & $2-1$ \\
\hline I.S.O. 14001 & Low & High & High & $1-2$ \\
\hline EMAS & Low & High & Low & $3-2$ \\
\hline EFQM & Low & High & Low & $1-2$ \\
\hline World Pact & Low & High & Low & $1-2$ \\
\hline Forética SGE-21 & Low & High & Low & $1-2$ \\
\hline \multicolumn{5}{|l|}{ Products with social responsibility } \\
\hline Micro-credits & High & High & Low & $1-3,2-3$ \\
\hline Preferred credits and loans & Low & High & High & $1-2$ \\
\hline \multicolumn{5}{|l|}{ Other } \\
\hline Report on number of received customer complaints & High & High & Low & $1-3,2-3$ \\
\hline $\begin{array}{l}\text { Ethics code applied when there are doubts about the meaning of } \\
\text { dispositions }\end{array}$ & High & Low & Low & $1-2$ \\
\hline Advises its customers on the use of its Web page & Medio & High & Low & $2-3$ \\
\hline Male immigrant individuals & Low & High & Medio & $1-2$ \\
\hline Female immigrant individuals & Low & High & Medio & $1-2$ \\
\hline
\end{tabular}

$$
\text { Source: author }
$$

As it can be seen from the results in Table 3, significant differences are obtained among the three clusters of credit institutions for most of the variables. Moreover, the membership of each of these clusters is not independent of the entity type (savings bank, credit union or bank). Thus, while cluster 1 shows a clear predominance of banks and credit unions, in the second one the presence of savings banks is dominant, and in the last one, credit unions have a greater weight.

From the differences between groups in terms of the clustering variables, i.e., the relative importance of the different stakeholders, we have labelled each of the clusters according to how they conceive of social responsibility, namely: responsibility focused on employees in the case of the first cluster, responsibility centred on society in the second one, and on regulatory responsibility in cluster 3 .

Thus, in the first cluster we find that we have named entities with responsibilities focused on employees, whose priority stakeholders are shareholders and employees, and which are made up mainly of banks and credit unions. These institutions develop activities which reconcile work and personal life, mainly in connection with children and adoption, to a greater extent than other clusters. The social activities which they develop are focused mainly on educational projects, and their contribution is in cash. With regards to standards, they are more generalist, and focus more on the (AA) 1000. It should be borne in mind that the application of this norm is basically in the formalization of the commitment to stakeholders.

Considering the actions towards customers, when questions arise about the meaning of its provisions, the number of complaints received from customers is reported, and the ethical code is applied. The socially-responsible products linked to this type of cluster are micro-credits.

These agencies give priority to the credit institution itself. According to this vision, the company should remain essentially within the market and should not get involved in social issues, because that would create market distortions.

In a second cluster, we find the group of institutions whose conception of responsibility is that it should be society-centred. They are mainly savings and credit unions. Within the stakeholders, they act primarily in favour of customers, society and the environment. The activities of balancing work and family life are based on cases of serious illness among dependent relatives and on the care of children.

In their dealings with suppliers, they are characterized by their use of a purchasing procedure for suppliers of capital goods and by their use of open tenders, according to volumes and the type of service or product to be contracted.

These institutions differ from one another in their use of standards (ISO 14001, EMAS-2001, EFQM (European Foundation for Quality Management), the Global Compact and Foretica SGE-21), which give objective evidence of the development of social corporate responsibility, both at the internal operational and development level and at the external level (reputation). From the standpoint of environmental actions, they have an environmental policy and put into practice a sound environmental approach, in addition to standards which have already been mentioned.

Socially-responsible entities have an innate tendency to innovate in products and processes (Garcia et al., 2007). Among the products with social responsibility, microcredits and preferential credits and loans stand out, being also remarkable because these entities run their businesses in favour of immigrants, both male and female. As for their service to clients, customers are encouraged to use the website on which information about the company is displayed, and the number of complaints received from customers is reported; such behaviour is a clear sign of objectivity and transparency. Actions in the form of a social contribution are put into practice within management costs. 
This sensitivity and this proactive attitude towards changes in the environment of the socially-responsible organizations often attract the most dynamic, creative and best- educated professionals, who see in this type of credit institution a personal and professional challenge. This innovative culture in credit institutions belonging to the second cluster has its origins in the proximity and sensitivity to changes and trends in the market and in society in general. This attitude allows them to make changes in the composition of their products, improve the quality and safety of their production processes, increase the safety and quality of domestic activity, move forward in the competition for launching new products, in the implementation of different types of future legislation, etc. This way of seeing and developing organizational activity enables them to develop a series of competitive advantages over competitors and is a part of their culture.

The third cluster is made up of those credit institutions that have a limited compliance with CSR norms. They consist mainly of Savings Accounts and Credit Unions. We have therefore called this cluster regulatory compliance- centred responsibility. The actions affecting stakeholders focus on shareholders/owners, suppliers and the Public Administration. These groups are traditionalists from the point of view of stakeholders, who focus most on the owners/shareholders, as domestic stakeholders and on the regulatory compliance (legislation) with the Public Administration as stakeholder. Social activities are referenced in investments for community and cultural projects. In addition, they are based on another type of social action, different from the aspects asked about in the survey. Among products with social responsibility, they focus on preferential credits and loans.

Within the standards, they stand out due to the implementation of ISO 14001. Following H.1 it seems logical that not all interest groups are treated in the same way by the credit institutions, but there is a greater sensitivity to implement policies for external stakeholders. For this reason, the administration of a credit institution and the response to an interested party depend largely on the needs of that party.

Assessment of internal and external stakeholders according to cluster

\begin{tabular}{|c|c|c|c|c|c|c|}
\hline \multirow{2}{*}{ Assessment } & \multicolumn{2}{|c|}{ Internal stakeholders } & \multicolumn{2}{c|}{ External stakeholders } \\
\cline { 2 - 7 } & Cluster 1 & Cluster 2 & Cluster 3 & Cluster 1 & Cluster 2 & Cluster 3 \\
\hline$[0,3.5]$ & 0 & 2 & 1 & 24 & 3 \\
\hline$[3.5,4]$ & 2 & 8 & 2 & 1 & 9 \\
\hline$] 4,4.5]$ & 8 & 4 & 0 & 1 & 1 \\
\hline$] 4.5,7]$ & 16 & 1 & 2 & 0 & 2 \\
\hline Chi2 & \multicolumn{3}{|c|}{$40.02(\mathrm{p}<0.01)$} & \multicolumn{2}{|c|}{4} & 1 \\
\hline
\end{tabular}

As it can be seen in the contingency table which relates the three clusters of credit institutions to the emphasis placed by such entities on internal stakeholders (shareholders, employees, customers and suppliers), the assessment of these stakeholders is significantly higher in cluster 1 than in clusters 2 and 3. Accordingly, institutions focused on legislation/regulations attach less importance to domestic interest groups, than do institutions that swell the ranks of clusters 1 and 2 .

With regard to the observed frequencies for the three clusters of credit institutions in connection with the importance that these different institutions attach to external stakeholders (society, environment, government/ regulators), the valuation of these interest groups is significantly higher in cluster 2 , than in clusters 1 and 3 . It is a remarkable fact that the entities in the first cluster, whose concept of social responsibility is focused on employees, give little importance to external stakeholders, thus being consistent with the above-mentioned growing importance of internal stakeholders.

\section{Conclusions}

The financial system has deservedly placed itself at the centre of the hurricane which is the crisis, through some decisions which, like it or not, have eroded the confidence of other economic agents. There are many ideas and proposals which have pointed the finger at the sophistication and the "artificiality" of financial activity, especially after the outbreak of scandals in the financial systems of the most developed countries, and which have argued, if nor for a return to traditional business, then at least for greater clarity and transparency.

From the information analyzed by the programme of actions performed by the Spanish credit institutions within the framework of CSR, it can be concluded that CSR is a growing movement in the Spanish financial sector, in which there exists a huge potential in this field due to its role in financial intermediation and loan-granting.

Many Spanish banks have already begun to communicate their policies, practices and results in relation to social responsibility through their social responsibility reports, and have taken steps to manage risks with environmental criteria. In our environment, as has already been demonstrated in other countries (United Kingdom, France) the requirement for such reports to be transparent with investors about the social and environmental filters applied in the selection of portfolios, loans or investors will favour the application of such criteria.

After conducting a cluster analysis we found three groups of entities. In the first cluster there are institutions with responsibility focused on employees. It includes entities whose priority stakeholders are shareholders and employees. In the second cluster, we find institutions with responsibility focused on society. Among the stakeholders they act primarily towards customers, society and the environment. The third cluster is made up of institutions with responsibility focused on legislation (norms). The actions towards stakeholders focus on shareholders/ owners, suppliers and the Public Administration. In the 
third cluster, Friedman's vision, which considers the social responsibility of the credit institution as the maximization of Profit and fulfilment of the norm, may be clearly seen. Contrasting with this view, clusters 1 and 2 show the vision of Frederick et al., (1992), who argue that business activity should achieve social benefits in addition to financial benefits.

The awareness among banks and credit unions of the environment as a stakeholder is significantly lower than that of the savings banks, a fact which indicates that concern for environmental conservation is a priority for savings banks. Consistent with this finding, a large number of savings banks incorporate environmental criteria into their management policy and voluntarily commit themselves to the protection and defence of the environment on the conviction of compatibility between economic activity and environment and, at the same time, integrate environmental factors into their strategies and operations. The concern about CSR is becoming increasingly evident, not only because of the need of institutions themselves to manage properly their reputational risks, namely, ethical, social and environmental, but also because of the pressure from ruling bodies and governmental institutions, investors, customers and society in general, who increasingly demand more transparency and involvement on the part of credit institutions in favour of society and sustainable development.

In our case it is worth noting the application of the London Principles on Sustainable Finance, launched by the Corporation of London, which aim to give access to financial products to socially excluded individuals. In addition to the principles, the Corporation of London has published case studies of sustainable-development best practices for financial institutions, thereby ensuring the continuity of principles, upon applying the basic principle of continuous improvement.

\section{References}

Alexander, G., \& Buchholz, R. (1982). Corporate Social Responsibility and Stock Market Performance. Academy of Management Journal (21), 479-486.

Ayyagari, M., Demirguec-Kunt, A., \& Maksimovic, V. (2008). 'How Important Are Financing Constraints? The Role of Finance in the Business Environment'. World Bank Economic Review, 22 (3), $483-516$. http://dx.doi.org/10.1093/wber/lhn018

Baker, M., \& Collins, M. (2010). English Commercial Banks and Organizational Inertia: The Financing of SMEs. Enterprise \& Society, 11(1), 65-97.

Berrone, P., Surroca, J., \& Tribo, J. A. (2007). Corporate Ethical Identity as a Determinant of Firm Performance: A Test of the Mediating Role of Stakeholder Satisfaction. Journal of Business Ethics, 76, 35-53. http://dx.doi.org/10.1007/s10551-006-9276-1

Bigne, J. E., Andreu, L., Chumpitaz, R., \& Swaen, V. (2005). Percepcion de la Responsabilidad Social Corporativa: un Análisis Cross-Cultural. Universia Business Review (1), 14-27.

Black, E. L., Carnes, T. A., \& Richardson, V. J. (2000). The Market Valuation of Corporate Reputation. Corporate Reputation Review (3), 31-42. http://dx.doi.org/10.1057/palgrave.crr.1540097

Brickson, S. L. (2005). Organizational Identity Orientation: Forging a Link between Organizational Identity and Organizations Relations with Stakeholders. Administrative Science Quarterly, 50(4), 576-609.

Brickson, S. L. (2007). Organizational Identity Orientation: the Genesis of the Role of the Firm and Distinct Forms of Social Value. Academy of Management Review, 32(3), 864-888. http://dx.doi.org/10.5465/AMR.2007.25275679

Brummer, J. J. (1991). Corporate Responsibility and Legitimacy. An Interdisciplinary Analysis, New York, Greenwood Press.

Carroll, A. B. (1991). The Pyramid of Corporate Social Responsibility: Toward the Moral Management of Organizational Stakeholders, Business Horizons (34), 39-48. http://dx.doi.org/10.1016/0007-6813(91)90005-G

Carroll, A. B. (1999). Corporate Social Responsibility. Evolution of a Definitional Construct. Business \& Society, 38 (3), 268-295. http://dx.doi.org/10.1177/000765039903800303

Carroll, A. B., (1989). Ethics and Stakeholder Management. Business \& Society Cincinnati Ohio, South-Western Publishing Co., 2 ed., 1993.

Certo, S. C., \& Peter J. P. (1996). Direccion Estrategica, $3^{\mathrm{a}}$ ed., Irwin, Madrid.

Charlo Molina, M. J., \& Moya Clemente, I. (2010). El Comportamiento Financiero de las Empresas Socialmente Responsables. Investigaciones Europeas de Direccion y Economía de la Empresa (16), 15-25.

Clarkson, M. B. E. (1995). A Stakeholder Framework for Analyzing and Evaluating Corporate Social Performance. Academy of Management Review, 20 (1), 92-117.

Cuervo, A. (2005). La Maximización del Valor Para el Accionista Versus la Responsabilidad Social Corporativa Compatibilidad? Economistas, 106, 13-21.

Davis, R., \& Blomstrom, R. L. (1975). Business and Society: Environment and Responsibiliry, London, MacGrawHill, 3ed., 259.

Dunham L., \& Liedtka, J. (2006). The Development of Stakeholder Theory: An Idiosyncratic Approach. Business Ethics Quarterly (16), 23-42. http://dx.doi.org/10.5840/beq20061611 
Easterbrook, F. H., \& Fischel, D. R. (1991). The Economic Structure of Corporate Law. Harvard University Press, Cambridge.

EUROPEAN COMMISSION (2001). Libro Verde. Fomentar un marco europeo para la responsabilidad social de las empresas. Comisión de las Comunidades Europeas, Bruselas.

Evan, W. M., \& Freeman, R. E. (1979). A Stakeholder Theory of the Modern Corporation: Kantian Capitalism, en Beauchamp T. L. y Bowie N. E. Ethical Theory and Business, Prentice Hall, Englewood Cliffs, Nueva Jersey.

Frederick, W. C., Post, J. E., \& Davis, K. (1992). Business and Society: Corporate Strategy, Public Policy, Ethics. McGraw Hill, Nueva York.

Freeman, E. (1984). Strategic Management: a stakeholder approach, Pitman, Boston, MA.

Garcia de los Salmones, M. M., Rodriguez del Bosque, I., \& San Martín, H. (2007). The Corporate Social Responsibility as a Marketing Tool: Influence on Consumer Behaviour in Service Sector. Congreso Marketing Trends, París.

Goodpaster, K. E. (1998). Business Ethics and Stakeholders Analisys. Business Ethics Quarterly (1), 53-72.

Goodpaster, K. E. (1979). Business Ethics and Stakeholder Analysis in T. L. Beauchamp /N. E. Bowie, Ethical Theory and Business, Prentice-Hall, Englewood Cliffs, New Jersey, 4 ed. (1993), 85-93.

Hair, J. F. (1995). Multivariate Data Analysis with Readings. Edit. Prentice Hall International.

Hatcher, L., \& Stepanski, E. J. (1994). A Step-By-Step Approach to Using the SAS System for Univariate and Multivariate statistics. SAS Inst. Inc., Cary, NC.

Henriques, I., \& Sadorsky, P. (1999). The Relationship between Environmental Commitment and Managerial Perceptions of Stakeholder Importance. Academy of Management Journal, 42 (1), 87-99. http://dx.doi.org/10.2307/256876

Johnson, D. E. (1998). Metodos Multivariados Aplicados al Analisis de Datos. Internacional Thomson Editores.

Jones, T., Felps, W., \& Bigley, G. A. (2007). Ethical Theory and Stakeholder-Related Decisions: The Role 174 Eleanor R. E. O'Higgins of Stakeholder Culture'. Academy of Management Review, 32(1), $137-155$. http://dx.doi.org/10.5465/AMR.2007.23463924

Kay, J. (1997). The Stakeholder Corporation, in G.2 Kelly, D. Kelly, and A. Gamble (eds.), Stakeholder Capitalism, Chapter 12 (Macmillan Press Ltd., Basingstoke, Hampshire, UK), 125-141.

Kessler, O. (2008). Uncertainty, Rationality and the Study of Social Institutions. Review of Social Economy, 66 (4), 501522. http://dx.doi.org/10.1080/00346760801932692

Kitson, A., \& Campbell, R. (1996). The Ethical Organization. Ethical Theory and Corporate Behaviour, London, MacMillan Business.

Kolk, A. (2005). Corporate Social Responsibility in the Coffee Sector The Dynamics of MNC Responses and Code Development. European Management Journal 23 (2), 228-236. http://dx.doi.org/10.1016/j.emj.2005.02.003

Lee, R. D., \& Miller, T. (1990). Population-Growth, Externalities to Childbearing, and Fertility Policy in DevelopingCountries. World Bank Economic Review. Supplement: S, 275-304.

Lozano, J. M., Albareda, L., \& Ysa, T. (2005). Que Pueden Hacer Los Gobiernos Para Promover la Responsabilidad Social de la Empresa (RSE)?. CIRIEC-España, Revista de Economía Pública, Social y Cooperativa, 53, 53-64.

Lozano, J. F. (1997). La Etica en la Direccion Empresarial: Participacion y Responsabilidad en A. Cortina (dir.), Rentabilidad de la Etica Para la Empresa, Madrid, Visor, 83-121.

Moir, L. (2001), What do we Mean by Corporate Social Responsibility?. Corporate Governance - the International Journal of Business in Society, 1(2), 16-22. http://dx.doi.org/10.1108/EUM0000000005486

Moskowitz, M. (1972). Choosing Socially Responsible Stocks, Business and Society (1), 71-75.

Pearson, R. (2005). Finance, Intermediaries, and Economic Development. Enterprise \& Society, 6 (1), $147-149$. http://dx.doi.org/10.1093/es/khi005

Phillips, R. A. (2003). Stakeholder Theory and Organizational Ethics, (Berrett-Koehler Publishers, Inc., San Francisco).

Porter, M. E., \& Kramer, M. R. (2006). Estrategia Sociedad: el Vinculo Entre la Ventaja Competitiva y la Responsabilidad Social Corporativa, Harvard Business Review 84 (12), 42-56.

Pruzan, P. (2001). The Question of Organizational Consciousness: Can Organizations Have Values, Virtues and Visions?. Journal of Business Ethics, 29, 271-284. ttp://dx.doi.org/10.1023/A:1026577604845

Scholtens, B. (2006). Finance as a Driver of Corporate Social Responsibility. Journal of Business Ethics, 68, 19-33. http://dx.doi.org/10.1007/s10551-006-9037-1

Tuleja, T. (1987). Mas alla de la Cuenta de Resultados. Barcelona, Plaza \& Janes, 58-80.

Uriel, E. (1995). Analisis de datos. Series temporales y analisis multivariante. Ed AC.

Van de Ven, B. (2008). An Ethical Framework for the Marketing of Corporate Social responsibility. Journal of Business Ethics, 82, 339-352. http://dx.doi.org/10.1007/s10551-008-9890-1

Waddock, S., \& Graves, S. (1997). Finding the link between Stakeholder Relations and Quality of Management. Business and Society 36 (3), 250-279. http://dx.doi.org/10.1177/000765039703600303 
Wheeler, D. W., \& Sillanpaa, M. (1997). The Stakeholder Corporation. A Blueprintfor Maximizing Stakeholder Value, London, Pitman Publishing.

Antoni Seguí-Alcaraz

Akcininkų koncepcija pagrịstų Ispanijos kredito ịstaigų klasifikavimo vystymasis

Santrauka

Bendroji socialinė atsakomybė (CSR) mano, kad bankai ị savo ekonominę veiklą ir santykius su dalyviais savanoriškai įtraukia socialinius ir ekonominius kriterijus. CSR dvišalius ryšius tarp akcininkų ir darbuotojų paverčia ị daugiašalius ryšius, kuriuose dalyvauja visi dalyviai, (akcininkai, darbuotojai, vartotojai, tiekèjai, vyriausybè, investuotojai, vietinė bendruomenè ir visuomenè ).

Dèl šių ryšių sustiprèja ne tik kredito ịstaigos ịvaizdis, bet didejja pasitikèjimas ja, suvokiama šios ịstaigos verte ir išskirtinumas. Taigi socialinis aspektas stiprèja.

Šio tyrimo tikslas yra rasti skirtingus kredito įstaigų profilius ir nustatyti jų įtaką bankams, atsižvelgiant i jụ suinteresuotumo CSR laipsnị ir svarba skirtingiems dalyviams.

Kredito įstaigos yra ịsipareigojusios teikti individams finansines paslaugas (t. y. santaupos ar einamosios sąskaitos, paskolos, pavedimai, patarimai ir t.t.). Visa tai teikti siekiama kuo palankesnèmis sąlygomis, kurios pasireiškia apyvartos, kaštu ir rizikos išraiška. Ši galimybe dažniausiai yra suteikiama tiems individams, kurie turi potencialą tapti pelningais vartotojais.

CSR pateikia naują, platesnę ir daugiau apimančią kredito įstaigu koncepciją, nes ji apima ne tik ekonominius, bet taip pat ir socialinius bei aplinkosaugos aspektus. Taigi Carroll (1991) darbe teigiama, kad CSR reikalauja, kad kredito įstaigos bandytų atitikti ekonominius, teisinius ir diskrecinius visų dalyvių, ne tik akcininkų, lūkesčius. Todèl, CSR yra artimai susijusi su trimis principais, kurie nukreipia plètotę ị ekonominę gerovę, integravimąsi ị aplinką ir socialinę lygybę.

Pastebima, kad finansinès grupès (apžvelgiant jų veiklą tarptautiniu mastu), vis dažniau leidžia socialinei ir aplinkosaugos politikai atlikti daug svarbesnị vaidmenį, kurị vis geriau vertina darbuotojai, vartotojai, investuotojai ir visa visuomenè. Už šios politikos slypi bendra koncepcija: socialiai atsakingi bankų veiksmai yra geri ne tik tuo, kad jie yra, bet ir kaip strateginė investicija, kuri duoda naudą įstaigoms. Todėl atitinkama socialinė ir aplinkosaugos politika daro teigiamą įtaką ne tik visuomenei, kurioje tai egzistuoja, tačiau ir jos įvaizdžiui bei ekonominei plètrai. Kaip politikos įtakos rezultatas ji taip pat turi įtaką trims pagrindinėms grupėms: darbuotojams, vartotojams, ir savininkams/akcininkams. Be to, finansuodamos, kredito ìstaigos nemažai prisideda prie visų projektų ir veiklos diegimo.

Bankų valdymas yra specializuotas, todèl banko vadovas yra įsipareigojęs /sudaręs sutarti vadovauti organizacijai. Svarbu paaiškinti, kad vadovai socialiniuose bankuose bando optimizuoti daugumos dalyvių interesus pagal banko ideologiją ir principus (etiniai ịsipareigojimai).

Praktinis tyrimas buvo atliktas naudojant apklausą, kurioje dalyvavo 57 Ispanijos kredito įstaigos. Norint nustatyti analizès diapazoną, dėmesys sutelktas i didžiausias Ispanijos kredito įstaigas. Tyrime panaudotas ịstaigos ịsipareigojimu kriterijus daugiau nei 700 milijonu „,vartotoju fondu" euru.

Remiantis Klasterio metodu arba klasterio klasifikacija, visos kredito ịstaigos padalinamos ị tam tikras grupes. Po to patvirtinamas modelis, norint ịsitikinti, kad sprendimas yra tipiškas visuomenei ir jị bus galima pritaikyti kitoms, i pavyzdi neịtrauktoms kredito įstaigoms bei jis laikui einant išliks nepakitusiu.

Norint ịdiegti kredito ịstaigų požiūrio ị CSR ịvertinimo metodą, pirmiausia bus nustatyta Ispanijos kredito ịstaigų taksonomija. Atlikus klasterio analizę, gaunamos trys grupès. Pirmame klasteryje yra įstaigos, kurių atsakomybė sutelkta ị darbuotojus. Jis apima įstaigas, kurios teikia pirmenybę tiems dalyviams, kurie yra akcininkai ir darbuotojai. Antrame klasteryje yra įstaigos, kurių atsakomybė yra sutelkta ị visuomenę. Tarp dalyvių jos pirmiausia išskiria vartotojus, visuomenę ir aplinkosaugą. Trečią klasterị sudaro ịstaigos, kuriu atsakomybe yra sutelkta i įstatymus (normas). I dalyvius nukreipti veiksmai sutelkiami i akcininkus/savininkus, tiekejjus ir viešaji administravimą. Trečiame klasteryje galima aiškiai pamatyti Friedman viziją, kuri laiko kredito įstaigų socialinę atsakomybę pelno maksimizavimu ir normų įvykdymu.

Susirūpinimas dèl CSR tampa vis svarbesniu ne tik todèl, kad pačioms ịstaigoms reikia tinkamai valdyti savo reputacijos rizika ( etinę, socialinę ir aplinkosaugos), bet taip pat ir dèl vadovaujančių institucijų ir vyriausybinių įstaigų, investuotojų, vartotojų ir visuomenės spaudimo, kurie vis dažniau reikalauja daugiau skaidrumo ir dalies kredito įstaigų dalyvavimo, vykdant ilgalaikius visuomenès plètros planus.

Taip pat šiame tyrime atlikta Tukey post-hoc analizè, siekiant sugretinti žymius skirtumus elementu porose.

Daug taupomujjų bankų įtraukia aplinkosaugos kriterijų ị savo valdymo politiką ir savanoriškai patys ịsipareigoja saugoti ir ginti gamtą, įsitikinę suderinamumu tarp ekonominès veiklos ir aplinkos, taip ịtraukdami aplinkosaugos veiksnius ị savo strategijas ir veiksmus.

Raktažodžiai: bendroji socialine atsakomybe , bankai, taksonomija, darbuotojai, visuomene, ịstatymai.

The article has been reviewed.

Received in October, 2011; accepted in December, 2012. 